\title{
A Pharmacological Study of Gastric Antiulcer Activity of the Leaf Extracts of Moringa oleifera Linn
}

\section{Dibyajyoti Deka ${ }^{1}$, Mangala Lahkar $^{1}$, Himadri Sekhar Dasgupta ${ }^{2}$, Dhriti KR Brahma $^{2 *}$ and Tirtha Chaliha ${ }^{1}$}

${ }^{1}$ Gauhati Medical College and Hospital, Guwahati, India

${ }^{2}$ North Eastern Indira Gandhi Regional Institute of Health and Medical Sciences

(NEIGRIHMS), Shillong, India

*Corresponding Author: Dhriti KR Brahma, North Eastern Indira Gandhi Regional Institute of Health and Medical Sciences (NEIGRIHMS), Shillong, India.
Received: May 08, 2021

Published: July 19, 2021

(C) All rights are reserved by Dhriti KR

Brahma., et al.

\begin{abstract}
Moringa oleifera Linn., a fast growing, drought resistant tree, is widely grown in Indian subcontinent and South Asia. The leaves of this tree have immense nutritional value. It is conventionally used by the people of the region as a traditional cure of many ailments including gastric ulcer. Diverge groups of Wistar rats belonging to different sexes were treated with pyloric ligation and by cold and restraint stress for induction of ulcer experimentally. The induced animals were treated with aqueous extracts of fresh leaves of $M o$ ringa oleifera (MOL) in the doses of $200 \mathrm{mg}$ and $400 \mathrm{mg}$ per $\mathrm{kg}$ as anti-ulcer cure and were compared with standard anti-ulcer drug Ranitidine. The study revealed the antiulcer activity of aqueous extract of leaves of MOL in animal models of pyloric ligation and cold restraint induced gastric ulcers. The ulcer protection in ranitidine group was $64.12 \%$ against the groups treated with MOL in doses of 200 and $400 \mathrm{mg} / \mathrm{kg}$ was $45.2 \%$ and $50.07 \%$, respectively. The acute toxicity study by the administration of doses of MOL up to $2000 \mathrm{mg} / \mathrm{kg}$ in the above for a period of 14 days did not show any acute toxicity. The satisfactory evidence of antiulcer activity of MOL extract suggests the necessity of further advanced scientific study for testing its usefulness in human.
\end{abstract}

Keywords: Moringa oleifera Linn.; Gastric Ulcer; Antiulcer Activity

\section{Introduction}

Peptic ulcer is associated with acute or chronic inflammation and is the most common gastrointestinal disorder in clinical practice around the world and is caused mostly by damage to mucosal lining of stomach or duodenum. Imbalance between the protective factors and acid secretion may substantially contribute its causation [1]. The incidence of peptic ulcer disease in the world is 1 to 1.9 per 1000 and the prevalence based on physician diagnosis is $0.12-1.50 \%$ [2]. Though several antiulcer drugs are available which reduce acid secretion, enhance gastric protection, prevent apoptosis or incite epithelial cell proliferation for healing, multiple adverse reactions and high rate of relapses are known with the use of such conventional drugs [3]. The potential natural drugs may cause lesser adverse reactions or to a minimum extent.

The earlier reports revealed that nature of food consumed like spicy food, food containing caffeine etc. incite gastric acid secretion in the stomach [4] and makes vulnerable to ulcer. Surprisingly, the people of south Asian countries suffer less due to duodenal ulcer and it was revealed that they frequently consume leaves of Moringa oleifera Linn. (Moringaceae) as a preventive measure which is speculated to protect against ulcers [5]. Moringa oleifera, a drought-resistant tree belonging to the family Moringaceae, subclass Dilleniidae and family Moringaceae, is native to the Indian subcontinent. The common names of the plant include moringa, 
drumstick tree, horseradish tree, and ben oil tree or benzolive tree. Several reports [6,7] [8] stated that origin of the tree is from the northern India. More specifically, wild habitat of Moringa oleifera stands only in hilly lowlands of north western India and thus is the actual centre of origin [9]. This is one of the fast growing, evergreen, deciduous medium sized perennial tree of about $10 \mathrm{~m}$ to $12 \mathrm{~m}$ height. Moringa oleifera is rich in fairly unique group of phytochemicals, glucosinolates and isothiocyanates [10,11]. Moringa oleifera leaves contain high quantity of vitamin A, calcium, iron, vitamin $C$ and potassium and protein which are of better quality than milk and eggs [11-13]. Different parts of this plant have been used as foods as well as medicinal purposes. Traditionally, M. oleifera leaves are used to treat many ailments, such as nervous debility, paralysis, asthma, diabetes, blood pressure, diarrhoea, infection and ulcer [14,15] and anti-ulcer properties [16,17]. Moringa has been reported to possess all powerful anti-oxidants that help in the detoxification of harmful compounds in the body. The flower bud of Moringa pteygosperma Linn., a synonym of Moringa oleifera Linn., widely consumed in Pakistan, was reported to possess antiulcer activity against aspirin-induced gastric ulcers in rats [18].

\section{Materials and Methods}

The study was carried out in the Department of Pharmacology, Gauhati Medical College and Hospital, Guwahati after getting necessary approval from the Institutional Animal Ethics Committee of Gauhati Medical College and Hospital, Guwahati with CPCSEA Registration No. 351: 03/01/2001 and study protocol approval No. MC/05/2015/88).

The experiment was conducted with 54 Wistar rats of either sex having the weight in the range of 150-250 grams. All the animals were kept in the Animal House of our Institute, in a clean area. The temperature was maintained at $24 \pm 2^{\circ} \mathrm{C}$, with relative humidity of $30-70 \%$, with alternate light and dark cycle of 12 hours. Six rats were kept in a polypropylene cage during the study. Cages had a stainless-steel top grill having facilities for food and drinking water in polypropylene bottles with stainless steel sipper tube. Standard rat pellet feed and pure drinking water were provided ad libitum. Maintenance of the study animals was done strictly following the CPCSEA guidelines.

\section{Materials}

Drugs and chemicals: (1) Ranitidine (2) Aqueous extract of Mor- inga oleifera (3) Normal Saline (0.9\% NaCl) (4) Topfer Reagent (5) $0.1 \mathrm{~N} \mathrm{NaOH}$ solution (6) Phenolphthalein solution

Plant material

Fresh leaves of MOL were collected from botanical garden in the month of September, 2016. Authentication and verification of the plants were done by Dr. Gajendra Sharma, Department of Botany, Gauhati university.

\section{Preparation of aqueous extract}

The leaves were thoroughly washed and shade dried, grinded into fine powders and were kept in air tight containers. The soxhlet apparatus was used for extraction. The resultant extracts were filtered using Whatman filter paper no. 1 , concentrated by evaporation and collected in petri dishes. The final yield of MOL leaf extracts were 66.3 grams $(26.5 \%)$, stored in a refrigerator at $4^{\circ} \mathrm{C}$ in air tight containers.

\section{Acute toxicity tests [19]}

This was carried out as per OECD guidelines. The rats were randomly selected, marked for identification, and kept in their cages for seven days prior to dosing. Animals were fasted prior to dosing (food was withheld for 3 - 4 hours). The dose was calculated according to the fasted body weight. Post fasting, the first animal was dosed at $175 \mathrm{mg} / \mathrm{kg}$ body weight with aqueous extract of study drug by gavage. Food was withheld for a further 1 - 2 hours. The animal was observed for mortality for 48 hours. Then a second animal was dosed at $550 \mathrm{mg} / \mathrm{kg}$ body weight by the same process. Again after 48 hours a third animal was dosed at $2000 \mathrm{mg} / \mathrm{kg}$ and observed for the next 48 hours for mortality. All the above animals were observed for a period of 14 days and were found to be alive at $2000 \mathrm{mg} / \mathrm{kg}$. Two doses of the study drug were selected i.e. 200 $\mathrm{mg} / \mathrm{kg}$, and $400 \mathrm{mg} / \mathrm{kg}$.

\section{Study groups}

The study had 2 experimental models.

- $\quad$ Ulcer induction by pyloric ligation [20]

- $\quad$ Ulcer induction by cold and restraint stress [21].

For each model, 5 groups of 6 animals each were selected. Group I (Normal control) served as a common for both models. Thus, for both models, a total of 54 animals were taken, detailed as follows $[22,23]$. 


\begin{tabular}{|l|c|c|}
\hline Groups & Group code & Treatment given \\
\hline Normal Control & NC & $\begin{array}{c}\text { No induction or inter- } \\
\text { vention given }\end{array}$ \\
\hline Disease Control & DC & Normal saline $1 \mathrm{ml} / \mathrm{kg}$ \\
\hline Standard & R20 & Ranitidine $20 \mathrm{mg} / \mathrm{kg}$ \\
\hline $\begin{array}{l}\text { Moringa oleifera aque- } \\
\text { ous extract low dose }\end{array}$ & AEMK200 & $\begin{array}{l}\text { Moringa oleifera } \mathrm{aque}- \\
\text { ous extract } 200 \mathrm{mg} / \mathrm{kg}\end{array}$ \\
\hline $\begin{array}{l}\text { Moringa oleifera aque- } \\
\text { ous extract high dose }\end{array}$ & AEMK400 & $\begin{array}{l}\text { Moringa oleifera } \mathrm{aque}- \\
\text { ous extract } 400 \mathrm{mg} / \mathrm{kg}\end{array}$ \\
\hline
\end{tabular}

Table 1

Duration and route of drug administration: All study drugs were administered orally for 7 days, using an oral feeding tube for rats.

\section{Study procedure}

- Ulcer induction by pylorus ligation by Shay's method: Under proper aseptic and antiseptic conditions, ulcer induction was done by pylorus ligation as per the standard procedure [20].

- Ulcer induction by cold and restraint stress by Vincent., et al: Under proper aseptic and antiseptic conditions, the animals were starved and on 7th day, ulcers were induced by cold while putting the animal in restraint [21].

Variables assessed in the study [25]

Following variables were measured in both models in the study:

- $\quad$ Ulcer index

- $\quad$ Percentage of ulcer protection. Additionally, following variables were studied in pyloric ligation model:

- Gastric content volume

- Free acidity

- Total acidity

- $\mathrm{pH}$

\section{Estimation of variables}

The ulcers were evaluated quantitatively using ulcer index and scoring number [26]. Percentage ulcer protection was also calculated. Volume, $\mathrm{pH}$, free and total acidities of gastric content was determined. Titration was done with $0.01 \mathrm{~N} \mathrm{NaOH}$, till total acidity was achieved.

\section{Histopathological examination}

Stomach tissues were fixed in $10 \%$ formalin for $24 \mathrm{hrs}$, and then embedded in paraffin. Small sections were made $(3-5 \mu \mathrm{m})$ and stained with H\&E dye and examined under light microscopy.

Statistical analysis:

- $\quad$ Analysis done using the Graph pad prism 5.01software.

- Between the groups, the data was compared using one way ANOVA test followed by post hoc Tukey's test [31]

- The level of significance for each comparison in the analysis was calculated at 0.05 .

\section{Results}

Pyloric ligation induced ulcer model

- Ulcer index: On comparison using one-way ANOVA, the mean ulcer index between the groups was significantly different $(\mathrm{P}<0.001)$ (Table 2). On post hoc analysis, it was higher in all pyloric ligated groups than the normal control group. In all treatment groups, the mean ulcer index was significantly lower than the disease control group $(\mathrm{P}<0.001)$. On comparison with ranitidine treated group, it was significantly higher in aqueous extract Moringa oleifera $200 \mathrm{mg} / \mathrm{kg}(\mathrm{p}=0.002)$ and $400 \mathrm{mg} / \mathrm{kg}(\mathrm{p}=0.041)$. The mean ulcer index in the groups treated with both doses of MOL were comparable $(p=0.92)$ as shown in table 3.

- Percentage of ulcer protection: Compared to the disease control group, the ulcer protection in ranitidine group was $64.12 \%$; in groups treated MOL in doses of 200 and $400 \mathrm{mg} /$ $\mathrm{kg}$, it was $45.2 \%$ and $50.07 \%$, respectively (Table 4 ).

- Volume of gastric juice: On comparison using one-way ANO$\mathrm{VA}$, the mean volume of gastric juice between the groups was significantly different $(\mathrm{P}<0.001)$ (Table 2$)$. On post hoc analysis, volume was significantly higher $(\mathrm{P}<0.001)$ in induced groups than the normal control group. It was significantly lower in the ranitidine $(\mathrm{P}<0.001)$, Moringa oleifera $400 \mathrm{mg}$ / $\mathrm{kg}(\mathrm{p}=0.042)$ treated groups than the disease control group. Compared to ranitidine treated group, the mean volume in MOL $200 \mathrm{mg} / \mathrm{kg}(\mathrm{P}<0.001)$ and $400 \mathrm{mg} / \mathrm{kg}(\mathrm{p}=0.001)$ was significantly higher (Table 3).

- $\quad$ pH of gastric juice: On comparison using one-way ANOVA, the mean $\mathrm{pH}$ of gastric juice between the groups was significantly different $(\mathrm{P}<0.001)$ (Table 2). On post hoc analysis, the mean $\mathrm{pH}$ was significantly lower in the disease control $(\mathrm{P}<0.001)$ 
and AEMK200 (P < 0.001) groups than normal control. The mean $\mathrm{pH}$ was significantly higher in the all treatment groups than the disease control group $(\mathrm{P}<0.001)$. On comparison with ranitidine treated group, the mean $\mathrm{pH}$ of gastric juice in MOL $200 \mathrm{mg} / \mathrm{kg}(\mathrm{P}<0.001)$ treated groups was significantly lower. The mean $\mathrm{pH}$ in the group treated with MOL $400 \mathrm{mg} /$ $\mathrm{kg}(\mathrm{P}<0.001)$ was significantly higher than the $200 \mathrm{mg} / \mathrm{kg}$ treated group (Table 3).

- Free acidity of gastric contents: On comparison using oneway ANOVA, it was observed that the mean free acidity of gastric juice between the groups was significantly different $(\mathrm{P}<$ 0.001 ) (Table 2). On post hoc analysis, it was observed that the mean free acidity of gastric juice was significantly higher $(\mathrm{P}<$ 0.001) in all induced groups than the normal control group. The mean free acidity of gastric juice was significantly lower in the all treatment groups than the disease control group $(\mathrm{P}$ $<0.001$ ). On comparison with ranitidine treated group, the mean free acidity of gastric juice in aqueous extract MOL 200 $\mathrm{mg} / \mathrm{kg}(\mathrm{P}<0.001)$ and $400 \mathrm{mg} / \mathrm{kg}(\mathrm{P}<0.001)$ treated groups was significantly higher. The mean free acidity of gastric juice in the group treated with aqueous extract MOL $400 \mathrm{mg} / \mathrm{kg}(\mathrm{P}$ $<0.001$ ) was significantly lower than the $200 \mathrm{mg} / \mathrm{kg}$ treated group (Table 3 ).

- Total acidity of gastric contents: On comparison using oneway ANOVA, it was observed that the mean total acidity of gastric juice between the groups was significantly different $(\mathrm{P}<0.001)$ (Table 2). On post hoc analysis, it was observed that the mean total acidity of gastric juice was significantly higher $(\mathrm{P}<0.001)$ in all induced groups than the normal control group. The mean total acidity of gastric juice was lower in the all treatment groups than the disease control group (P $<0.001$ ). On comparison with ranitidine treated group, the mean total acidity of gastric juice in aqueous extract MOL 200 $\mathrm{mg} / \mathrm{kg}(\mathrm{P}<0.001)$ and $400 \mathrm{mg} / \mathrm{kg}(\mathrm{P}<0.001)$ treated groups was significantly higher. The mean total acidity of gastric juice in the group treated with aqueous extract MOL $400 \mathrm{mg} / \mathrm{kg}$ (P $<0.001$ ) was significantly lower than the $200 \mathrm{mg} / \mathrm{kg}$ treated group (Table 3).

\begin{tabular}{|c|c|c|c|c|c|c|c|c|}
\hline Groups & $\begin{array}{l}\text { Ulcer } \\
\text { index }\end{array}$ & $\begin{array}{c}\text { Volume } \\
\text { of gastric } \\
\text { juice }(\mathrm{ml})\end{array}$ & $\begin{array}{l}\text { Ph of gas- } \\
\text { tric juice }\end{array}$ & $\begin{array}{c}\text { Free acidity } \\
\text { of gastric } \\
\text { contents }\end{array}$ & $\begin{array}{l}\text { Total acid- } \\
\text { ity }\end{array}$ & Statistical & $\begin{array}{c}P \\
\text { value }\end{array}$ & Interpretation \\
\hline $\mathrm{NC}$ & 0 & $1.14 \pm 0.13$ & $3.08 \pm 0.11$ & $10.02 \pm 0.24$ & $18.47 \pm 0.38$ & \multirow{5}{*}{$\begin{array}{l}\text { One way } \\
\text { ANOVA }\end{array}$} & \multirow{5}{*}{$\begin{array}{c}\mathrm{P}< \\
0.001\end{array}$} & \multirow{5}{*}{$\begin{array}{l}\text { The mean ulcer index, } \\
\text { volume of gastric juice, ph } \\
\text { of gastric juice, free acidity } \\
\text { and total acidity of gastric } \\
\text { juice between the groups } \\
\text { was } \\
\text { significantly } \\
\text { different }\end{array}$} \\
\hline DC & $4.38 \pm 0.43$ & $3.31 \pm 0.34$ & $1.81 \pm 0.09$ & $30.94 \pm 1.56$ & $42.86 \pm 0.58$ & & & \\
\hline $\mathrm{R} 20$ & $1.57 \pm 0.32$ & $2.45 \pm 0.27$ & $3.26 \pm 0.11$ & $11.48 \pm 0.4$ & $24.34 \pm 1.09$ & & & \\
\hline AEMK200 & $2.4 \pm 0.44$ & $3.23 \pm 0.14$ & $2.54 \pm 0.22$ & $19.35 \pm 0.64$ & $32.6 \pm 0.58$ & & & \\
\hline AEMK400 & $2.19 \pm 0.37$ & $2.96 \pm 0.11$ & $3.12 \pm 0.09$ & $16.28 \pm 0.39$ & $28.14 \pm 0.88$ & & & \\
\hline
\end{tabular}

Table 2: Pyloric ligation model.

Effect on ulcer index, volume of gastric juice, Ph of gastric juice, free acidity of gastric juice and total acidity.

\begin{tabular}{|c|c|c|c|c|c|c|c|c|c|c|c|}
\hline \multirow[t]{2}{*}{$\begin{array}{c}\text { Group } \\
1 \\
\end{array}$} & \multirow[t]{2}{*}{$\begin{array}{c}\text { Group } \\
2\end{array}$} & \multicolumn{2}{|c|}{ Ulcer index } & \multicolumn{2}{|c|}{$\begin{array}{c}\text { Volume of gastric } \\
\text { juice }\end{array}$} & \multicolumn{2}{|c|}{ Ph of gastric juice } & \multicolumn{2}{|c|}{ Free acidity } & \multicolumn{2}{|c|}{ Total acidity } \\
\hline & & $\begin{array}{c}P \\
\text { value }\end{array}$ & $\begin{array}{l}\text { Interpre- } \\
\text { tation }\end{array}$ & $\begin{array}{c}P \\
\text { value }\end{array}$ & $\begin{array}{l}\text { Interpre- } \\
\text { tation }\end{array}$ & $\begin{array}{c}\mathbf{P} \\
\text { value }\end{array}$ & $\begin{array}{l}\text { interpreta- } \\
\text { tion }\end{array}$ & $\begin{array}{c}\mathbf{P} \\
\text { value }\end{array}$ & $\begin{array}{l}\text { Interpre- } \\
\text { tation }\end{array}$ & $\begin{array}{c}\mathbf{P} \\
\text { value }\end{array}$ & $\begin{array}{c}\text { Interpre- } \\
\text { tation }\end{array}$ \\
\hline \multirow{4}{*}{ NC } & DC & $<0.001$ & \multirow{4}{*}{$\begin{array}{l}\text { The mean } \\
\text { ulcer } \\
\text { index in } \\
\text { the other } \\
\text { groups } \\
\text { was sig- } \\
\text { nificantly } \\
\text { higher } \\
\text { than the } \\
\text { NC group }\end{array}$} & $<0.001$ & \multirow{4}{*}{$\begin{array}{l}\text { The mean } \\
\text { gastric } \\
\text { juice } \\
\text { volume in } \\
\text { the other } \\
\text { groups } \\
\text { was signifi- } \\
\text { cantly } \\
\text { higher than } \\
\text { the NC } \\
\text { group }\end{array}$} & $<0.001$ & \multirow{4}{*}{$\begin{array}{l}\text { The mean pH } \\
\text { was signifi- } \\
\text { cantly lower } \\
\text { in the DC, } \\
\text { AEMK200 } \\
\text { group than NC, } \\
\text { while it was } \\
\text { comparable } \\
\text { with NC group } \\
\text { in R20, and } \\
\text { AEMK400 } \\
\text { groups }\end{array}$} & $<0.001$ & \multirow{4}{*}{$\begin{array}{l}\text { The mean } \\
\text { free } \\
\text { acidity in } \\
\text { DC, R20, } \\
\text { AEMK200, } \\
\text { AEMK400 } \\
\text { groups } \\
\text { was sig- } \\
\text { nificantly } \\
\text { higher } \\
\text { than the } \\
\text { NC group }\end{array}$} & $<0.001$ & \multirow{4}{*}{$\begin{array}{c}\text { The mean } \\
\text { total } \\
\text { acidity in } \\
\text { DC, R20, } \\
\text { AEMK200, } \\
\text { AEMK400 } \\
\text { groups was } \\
\text { significant- } \\
\text { ly higher } \\
\text { than the } \\
\text { NC group }\end{array}$} \\
\hline & $\mathrm{R} 20$ & $<0.001$ & & $<0.001$ & & 0.309 & & 0.019 & & $<0.001$ & \\
\hline & $\begin{array}{l}\text { AEMK } \\
200\end{array}$ & $<0.001$ & & $<0.001$ & & $<0.001$ & & $<0.001$ & & $<0.001$ & \\
\hline & $\begin{array}{l}\text { AEMK } \\
400\end{array}$ & $<0.001$ & & $<0.001$ & & 0.998 & & $<0.001$ & & $<0.001$ & \\
\hline
\end{tabular}




\begin{tabular}{|c|c|c|c|c|c|c|c|c|c|c|c|}
\hline \multirow[t]{3}{*}{ DC } & R20 & $<0.001$ & \multirow{3}{*}{$\begin{array}{l}\text { The mean } \\
\text { ulcer index } \\
\text { in R20, } \\
\text { AEMK200, } \\
\text { AEMK400 } \\
\text { groups } \\
\text { was sig- } \\
\text { nificantly } \\
\text { lower than } \\
\text { the DC } \\
\text { group }\end{array}$} & $<0.001$ & \multirow{3}{*}{$\begin{array}{l}\text { The mean } \\
\text { gastric } \\
\text { juice vol- } \\
\text { ume was } \\
\text { significant- } \\
\text { ly lower in } \\
\text { the R20, } \\
\text { AEMK400 } \\
\text { group than } \\
\text { DC group, } \\
\text { while it } \\
\text { was com- } \\
\text { parable } \\
\text { with DC } \\
\text { group in } \\
\text { AEMK200 } \\
\text { groups }\end{array}$} & $<0.001$ & \multirow{3}{*}{$\begin{array}{l}\text { The mean } \\
\text { pH in R20, } \\
\text { AEMK200, } \\
\text { AEMK400 } \\
\text { groups was } \\
\text { significantly } \\
\text { higher than } \\
\text { the DC group }\end{array}$} & $<0.001$ & \multirow{3}{*}{$\begin{array}{c}\text { The mean } \\
\text { free acid- } \\
\text { ity in R20, } \\
\text { AEMK200, } \\
\text { AEMK400 } \\
\text { groups } \\
\text { was sig- } \\
\text { nificantly } \\
\text { lower } \\
\text { than the } \\
\text { DC group }\end{array}$} & $<0.001$ & \multirow{3}{*}{$\begin{array}{c}\text { The mean } \\
\text { total acid- } \\
\text { ity in R20, } \\
\text { AEMK200, } \\
\text { AEMK400 } \\
\text { groups was } \\
\text { significant- } \\
\text { ly lower } \\
\text { than the } \\
\text { DC group }\end{array}$} \\
\hline & AEMK & $<0.001$ & & 0.990 & & $<0.001$ & & $<0.001$ & & $<0.001$ & \\
\hline & $\begin{array}{c}\text { AEMK } \\
400\end{array}$ & $<0.001$ & & 0.042 & & $<0.001$ & & $<0.001$ & & $<0.001$ & \\
\hline \multirow[t]{2}{*}{ R20 } & $\begin{array}{c}\text { AEMK } \\
200\end{array}$ & 0.002 & \multirow[b]{2}{*}{$\begin{array}{l}\text { The mean } \\
\text { ulcer } \\
\text { index in } \\
\text { AEMK200 } \\
\text { groups } \\
\text { was sig- } \\
\text { nificantly } \\
\text { higher } \\
\text { than the } \\
\text { R20 group, } \\
\text { while it } \\
\text { was com- } \\
\text { parable } \\
\text { with R20 } \\
\text { group in } \\
\text { AEMK- } \\
\text { 400groups }\end{array}$} & $<0.001$ & \multirow{2}{*}{$\begin{array}{l}\text { The mean } \\
\text { gastric } \\
\text { juice vol- } \\
\text { ume was } \\
\text { significant- } \\
\text { ly higher } \\
\text { in the } \\
\text { AEMK200, } \\
\text { AEMK400 } \\
\text { than R20 } \\
\text { group }\end{array}$} & $<0.001$ & \multirow{2}{*}{$\begin{array}{l}\text { The mean } \\
\text { pH in R20, } \\
\text { AEMK200 } \\
\text { groups was } \\
\text { significantly } \\
\text { lower than } \\
\text { the R20 } \\
\text { group, while it } \\
\text { was compa- } \\
\text { rable with } \\
\text { R20 group in } \\
\text { AEMK400 }\end{array}$} & $<0.001$ & \multirow{2}{*}{$\begin{array}{l}\text { The mean } \\
\text { free } \\
\text { acidity in } \\
\text { AEMK200, } \\
\text { AEMK400 } \\
\text { groups } \\
\text { was sig- } \\
\text { nificantly } \\
\text { higher } \\
\text { than the } \\
\text { R20 group }\end{array}$} & $<0.001$ & \multirow{2}{*}{$\begin{array}{c}\text { The mean } \\
\text { total } \\
\text { acidity in } \\
\text { AEMK200, } \\
\text { AEMK400 } \\
\text { groups was } \\
\text { significant- } \\
\text { ly higher } \\
\text { than the } \\
\text { R20 group }\end{array}$} \\
\hline & $\begin{array}{c}\text { AEMK } \\
400\end{array}$ & 0.041 & & 0.001 & & 0.638 & & $<0.001$ & & $<0.001$ & \\
\hline $\begin{array}{c}\text { AEMK } \\
200\end{array}$ & $\begin{array}{c}\text { AEMK } \\
400\end{array}$ & 0.920 & $\begin{array}{c}\text { Mean ulcer } \\
\text { index was } \\
\text { compa- } \\
\text { rable } \\
\text { between } \\
\text { AEMK200 } \\
\text { and } \\
\text { AEMK400 } \\
\text { groups }\end{array}$ & 0.200 & $\begin{array}{l}\text { Mean gas- } \\
\text { tric juice } \\
\text { volume } \\
\text { was com- } \\
\text { parable } \\
\text { between } \\
\text { AEMK200 } \\
\text { and } \\
\text { AEMK400 } \\
\text { groups }\end{array}$ & $<0.001$ & $\begin{array}{l}\text { Mean pH was } \\
\text { significantly } \\
\text { higher in } \\
\text { AEMK400 } \\
\text { group than } \\
\text { AEMK200 } \\
\text { group }\end{array}$ & $<0.001$ & $\begin{array}{l}\text { Mean free } \\
\text { acidity } \\
\text { was sig- } \\
\text { nificantly } \\
\text { lower in } \\
\text { AEMK400 } \\
\text { group } \\
\text { than } \\
\text { AEMK200 } \\
\text { group }\end{array}$ & $<0.001$ & $\begin{array}{l}\text { Mean total } \\
\text { acidity was } \\
\text { significant- } \\
\text { ly lower in } \\
\text { AEMK400 } \\
\text { group than } \\
\text { AEMK200 } \\
\text { group }\end{array}$ \\
\hline
\end{tabular}

Table 3: Post hoc analysis using Tukey's test.

\begin{tabular}{|l|c|c|}
\hline \multirow{2}{*}{ Groups } & \multicolumn{2}{|c|}{$\begin{array}{c}\text { Percentage of ulcer protection compared to } \\
\text { disease control }\end{array}$} \\
\hline & Pyloric ligation method & Cold restraint method \\
\hline NC & - & - \\
\hline DC & - & - \\
\hline R20 & $64.12 \%$ & $67.9 \%$ \\
\hline AEMK200 & $45.2 \%$ & $47.49 \%$ \\
\hline AEMK400 & $50.07 \%$ & $54.82 \%$ \\
\hline
\end{tabular}

Table 4: Percentage of ulcer protection.
Cold Restraint stress induced ulcer model

- $\quad$ Ulcer index: On comparison using one-way ANOVA, it was observed that the mean ulcer index between the groups was significantly different $(\mathrm{P}<0.001)$ (Table 5$)$. On post hoc analysis, it was observed that in all induced groups, the mean ulcer index was significantly higher $(\mathrm{P}<0.001)$ than the normal control group. The mean ulcer index in all treatment groups, the mean ulcer index was significantly lower than the disease control group $(\mathrm{P}<0.001)$. On comparison with ranitidine 
treated group, the mean ulcer index in aqueous extract MOL $200 \mathrm{mg} / \mathrm{kg}(\mathrm{P}<0.001)$ and $400 \mathrm{mg} / \mathrm{kg}(\mathrm{p}=0.013)$ treated groups was significantly higher. The mean ulcer index in the groups treated with both doses of MOL were comparable $(\mathrm{p}=$ 0.4) (Table 6).
- Percentage of ulcer protection: Compared to the disease control group, the ulcer protection in ranitidine group was $67.9 \%$; in groups treated with aqueous extract of MKL in doses of 200 and $400 \mathrm{mg} / \mathrm{kg}$, it was $47.49 \%$ and $54.82 \%$, respectively (Table 4).

\begin{tabular}{|c|c|c|c|c|}
\hline Groups & Ulcer index & Statistical test & $\begin{array}{l}\text { F distribution } \\
\text { and } P \text { value }\end{array}$ & Interpretation \\
\hline NC & 0 & \multirow{5}{*}{$\begin{array}{l}\text { One way } \\
\text { ANOVA }\end{array}$} & \multirow{5}{*}{$\begin{array}{c}F(6,35)=139.8 \\
P<0.001\end{array}$} & \multirow{5}{*}{$\begin{array}{c}\text { The mean ulcer index between } \\
\text { the groups was significantly } \\
\text { different. }\end{array}$} \\
\hline DC & $3.76 \pm 0.44$ & & & \\
\hline $\mathrm{R} 20$ & $1.21 \pm 0.14$ & & & \\
\hline AEMK200 & $1.97 \pm 0.26$ & & & \\
\hline AEMK400 & $1.7 \pm 0.22$ & & & \\
\hline
\end{tabular}

Table 5: Cold restraint model.

\begin{tabular}{|c|c|c|c|}
\hline Group 1 & Group 2 & $P$ value & Interpretation \\
\hline NC & $\begin{array}{c}\text { DC } \\
\text { R20 } \\
\text { AEMK200 } \\
\text { AEMK400 }\end{array}$ & $\begin{array}{l}<0.001 \\
<0.001 \\
<0.001 \\
<0.001\end{array}$ & $\begin{array}{l}\text { The mean ulcer index in DC, R20, AEMK200, AEMK400 } \\
\text { groups was significantly higher than the NC group }\end{array}$ \\
\hline DC & $\begin{array}{c}\text { R20 } \\
\text { AEMK200 } \\
\text { AEMK400 }\end{array}$ & $\begin{array}{l}<0.001 \\
<0.001 \\
<0.001\end{array}$ & $\begin{array}{l}\text { The mean ulcer index in R20, AEMK200, AEMK400 } \\
\text { groups was significantly lower than the DC group. }\end{array}$ \\
\hline $\mathrm{R} 20$ & $\begin{array}{l}\text { AEMK200 } \\
\text { AEMK400 }\end{array}$ & $\begin{array}{c}<0.001 \\
0.013\end{array}$ & $\begin{array}{c}\text { The mean ulcer index in AEMK200, AEMK400 groups } \\
\text { was significantly higher than the R20 group }\end{array}$ \\
\hline AEMK200 & AEMK400 & 0.4 & $\begin{array}{c}\text { Mean ulcer index was comparable between AEMK200 } \\
\text { and AEMK400 groups }\end{array}$ \\
\hline
\end{tabular}

Table 6: Post hoc analysis using Tukey's test.

\section{Discussion}

The present study demonstrated the antiulcer activity of aqueous extract of leaves of MOL in animal models of pyloric ligation and cold restraint induced gastric ulcers. MOL leaf extract has demonstrated antiulcer activity in some animal studies. These plants are easily available throughout the country in abundance, thus, giving us the opportunity to develop a cheap and easily available alternative for management of peptic ulcers. Thus, these plants were chosen and their antiulcer efficacy was evaluated in comparison to that with ranitidine.

In the present study, induction of ulcer by pyloric ligation or cold restraint stress was seen in the disease control groups, which was evident from the increase in ulcer index in comparison to the normal control group. Other variables also differed significantly.

\section{Pyloric ligation induced ulcer model findings}

With treatment by aqueous extract of MOL, the ulcer index was lower compared to the disease control group, but higher compared to ranitidine. Dose dependent effect was not observed. The ulcer protection was $50 \%$ at $400 \mathrm{mg} / \mathrm{kg}$ dose and $45.2 \%$ at $200 \mathrm{mg} / \mathrm{kg}$ dose. The gastric juice volume was lower at $400 \mathrm{mg} / \mathrm{kg}$ dose compared to disease control group. Compared to ranitidine, at both doses the gastric volume was higher. The gastric $\mathrm{pH}$ was increased compared to disease control group. In comparison to ranitidine, only $400 \mathrm{mg} / \mathrm{kg}$ dose gave comparable results. $\mathrm{pH}$ was higher com- 
pared to $200 \mathrm{mg} / \mathrm{kg}$ dose, representing a dose dependent effect. The free and total acidity of gastric contents was reduced than disease control group, however, the effect was not comparable to the ranitidine group, and also a dose dependent effect was observed with better response at higher dose. These results revalidate the findings of some other previous studies [26-29].

\section{Cold restraint stress induced ulcer model findings}

The ulcer index in the aqueous extract of MOL at both doses was lower than the disease control group, but was higher than ranitidine group, and similar at both doses. The ulcer protection provided was lower than that by ranitidine treatment at both doses.

From the findings of the study, it was evident that the aqueous extracts of leaves of MOL have antiulcer activity. This activity measured in terms of ulcer index and ulcer protection was evident compared to the disease control group. Ulcer protection was found to be more at higher doses compared to the lower doses. The $\mathrm{pH}$, volume, free and total acidity represent secretory activity in the stomach. The effect on these variables demonstrated anti-secretory activity of the aqueous extract of MOL. Antiulcer activity of aqueous extract of Moringa oleifera leaves in the dose of $200 \mathrm{mg} / \mathrm{kg}$ and $400 \mathrm{mg} / \mathrm{kg}$ has been demonstrated in few studies. All the macroscopic and biochemical parameters showed significant antiulcer activity of Moringa oleifera. Study by Hamid., et al. [30] also showed significant anti-ulcer activity of Moringa oleifera aqueous extract like that of Rantidine, the positive control. Thus, the present study findings are in agreement with the previous studies evaluating the antiulcer activity of aqueous extract of leaves of MOL. However, the leaves contain numerous other phytoconstituents which have not yet been evaluated individually for their antiulcer potential.

\section{Conclusion}

The present study adds to the evidence of antiulcer efficacy of aqueous extracts of leaves of Moringa oleifera. Though not as efficacious as ranitidine, it is a promising agent possessing the potential antiulcer activity. Advanced research methodologies should be encouraged to identify and isolate the active phyto-constituents of the leaves of these native indigenous medicinal plants. The available evidence of antiulcer activity provides satisfactory evidence for further advanced studies with more pure and refined products for testing its efficacy in human. Development of compounds as antiulcer agents may have an additional advantage of being more cost effective.

\section{Conflict of Interest}

Nothing to declare.

\section{Bibliography}

1. Dandiya PC KS. "Introduction to Pharmacology". New Delhi: Vallabh Prakashan (2005).

2. Sung JJY., et al. "Systematic review: The global incidence and prevalence of peptic ulcer disease". Aliment Pharmacology Therapy 29.9 (2009): 938-946.

3. Piper DW. "A Comparative Overview of the Adverse Effects of Antiulcer Drugs". Drug Safety 12.2 (1995): 120-138.

4. Crawford JM. "Robbin's Pathologic Basis of Disease". New Delhi, India, Saunders (2003): 787-802.

5. Jayaraj AP., et al. "Possible dietary protective factors in relation to the distribution of duodenal ulcer in India and Bangladesh". Gut 21 (1998): 1068-1076.

6. Vogt K. "A field worker's guide to the identification, propagation and uses of common trees and shrubs of dryland Sudan". (1996): 167.

7. Maydell HJ von. "Trees and shrubs of the Sahel: their characteristics and uses". Eschborn, Germany: GTZ (1986).

8. Dalla Rosa KR. "Moringa oleifera: a perfect tree for home gardens". Agroforestry Species Highlights, 1. Paia, Hawaii, USA: Nitrogen Fixing Tree Association (1993).

9. Olsona ME. "Moringa frequently asked questions". Acta Horticulture (2017).

10. Fahey JW. "Moringa oleifera: A review of the medical evidence for its nutritional, therapeutic and prophylactic properties, Part 1". Trees for Life Journal 10.6 (2005): 1-5.

11. Bennett RN., et al. "Profiling glucosinolates and phenolics in vegetative and reproductive tissues of the multipurposetrees Moringa oleifera L. (Horseradieh Tree) and Moringa stenopetala L". Journal of Agricultural and Food Chemistry 51.8 (2003): 3546-3553.

12. Berger MR., et al. "Toxicological assessment of seeds from Moringa oleifera and Moringa stenopetala, two highly efficient primary coagulants for domestic water treatment of tropical raw waters". East African Medical Journal 61 (1984): 712-716.

13. Gassenschmidt U., et al. "Isolation and characterization of a flocculating protein from Moringaoleifera Lam". Biochemistry and Biophysics Acta 1243 (1995): 477-481. 
14. Mishra G., et al. "Traditional uses, phytochemistry and pharmacological properties of Moringaoleifera plant: an overview". Der Pharmacia Lettre 3 (2011): 141e64.

15. Promkum C., et al. "Nutritive evaluation and effect of Moringaoleifera pod on clastogenic potential in the mouse". Asian Pacific Journal of Cancer Prevention: APJCP 11 (2010): 627e32.

16. Rathnayake ARMHA., et al. "Moringaolifera plant and the nutritional and medicinal properties of Moringaolifera leaves". In the book: Trends and Prospects in Processing of Horticultural Crops (2019): 251-268 Editors: Ivi Chakraborty, Prodyut Kumar Paul, Arghya Mani, Arun Kumar Tiwary and K. Prasad Today and Tomorrow's Printers and Publishers, New Delhi - 110 002, India.

17. Singh N and Malik A. "Nutritional and Medicinal Properties of Moringa oleifera”. Agrospheres:e-Newsletter 1.6 (2020): 18-20.

18. Akhtar AH and Ahmad KU. "Anti-ulcerogenic evaluation of the methanolic extracts of some indigenous medicinal plants of Pakistan in aspirin-ulcerated rats". Journal of Ethnopharmacology 46 (1995): 1-6.

19. Organization for Economic Cooperation and Development. OECD guidelines for the testing of chemicals. Test no. 425: Acute Oral Toxicity - Up-and-Down-Procedure (UDP) (2008): $1-27$.

20. Shay H., et al. "A simple method for the uniform production of gastric ulceration in the rat". Gastroenterology 5 (1945): 43-61.

21. Vincent G., et al. "Body orientation, food deprivation and potentiation of restraint induced gastric lesions". Gastroentérologie Clinique et Biologique 1 (6-7): 539-543.

22. Dawson J., et al. "Ranitidine--pharmacology and clinical use". Journal of Clinical and Hospital Pharmacy 8.1 (1983): 1-13.

23. Chopra D., et al. "Anaphylaxis following intravenous ranitidine: A rare adverse reaction of a common drug". Indian Journal of Pharmacology 46.2 (2017): 234-236.

24. Mitchard M., et al. "Ranitidine drug interactions-a literature review”. Pharmacology Therapy 32.3 (1987): 293-325.

25. Ganguly AK. "A method for quantitative assessment of experimentally produced ulcers in the stomach of albino rats". Experientia 25 (1969): 1224.

26. Mitra PK. "Comparative Evaluation of Anti-Ulcer Activity of Root Stem and Leave of Murryakoenigii (Linn.) Spreng in Rats". Journal of Medicinal Plants Studies 1.3 (2013): 158-165.
27. Mitra PK., et al. "Isolation and characterization of an anti-ulcer compound from Murryakoenigii (linn.) Sprengwettst leaves”. International Journal of Pharmacy Practice and Drug Research 6.1 (1965): 29-35.

28. Das KC., et al. "Antifungal activity of some constituents of Murraya koenigii". Experientia 21.6 (1965): 340.

29. Kansara SS and Singhal M. "Evaluation of Antiulcer Activity of Moringa oleifera Seed Extract". Journal of Pharmaceutical and BioSciences 3.1 (2013): 20-25.

30. Hamid AK., et al. "Antiulcer Activity of Leaves Extract of Murraya koenigii In Experimentally Induced Ulcer In Rats". Pharmacology Online 2 (2011): 818-824.

31. Brillinger D. “The Collected Works of John W. Tukey” (1984).

\section{Volume 5 Issue 8 August 2021}

(C) All rights are reserved by Dhriti KR Brahma., et al. 